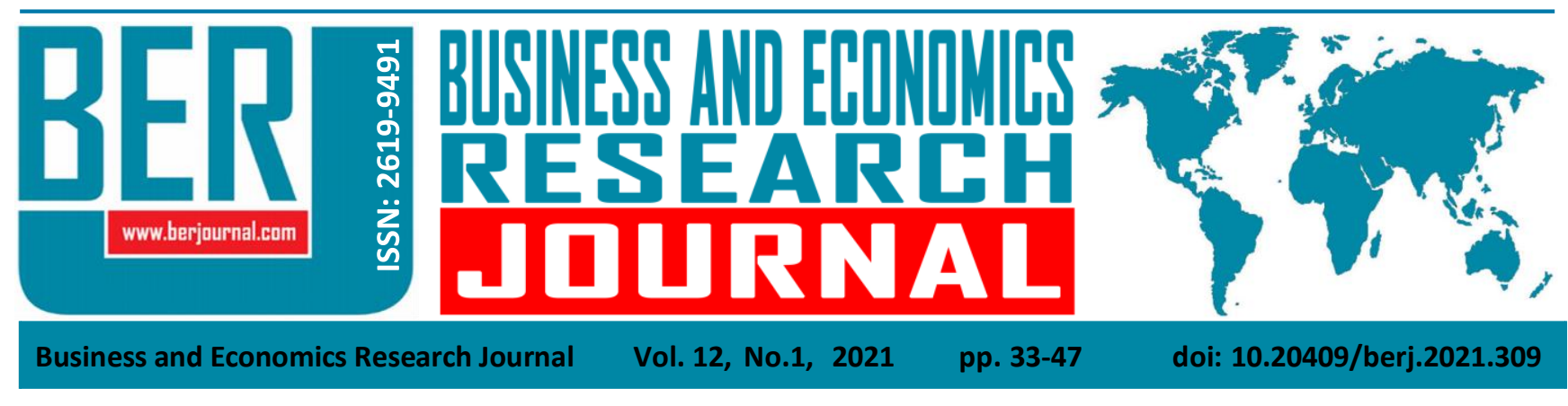

\section{Türkiye'de Tüketici ve Üretici Fiyatları Arasındaki İlişkinin Alternatif Tahmin Yöntemleri Kullanılarak Analizi}

\section{Necmettin Alpay Kocak ${ }^{\mathrm{a}}$}

Öz: Tüketici fiyatları ile üretici fiyatları arasındaki ilişki literatürde tartışılmaktadır. Bu çalışmada Türkiye için söz konusu ilişkinin varlığı ve boyutları, tüketici (TÜFE), üretici (Yi-ÜFE) ve tarım (TARIM-ÜFE) sektörlerine ilişkin yıllık enflasyon oranları arasında incelenmiştir. 2011 Ocak-2020 Haziran arasındaki dönemin analiz edildiği çalışmada, zaman serilerinin durağanlık özellikleri beş farklı test kullanılarak incelenmiştir. Zaman serileri arasındaki eş-bütünleşme ilişkisi standart Johansen, yapısal kırılmalı Johansen ve yapısal kırılmalı Lütkepol testleri ile araştırılmıştır. Fiyat endeksleri arasındaki ilișkinin kısa dönemli dinamikleri vektör hata düzeltme modeli ile araştırıldıktan sonra, literatürden farklı olarak, uzun dönemli ilişki katsayıları farklı ekonometrik tahmin yöntemleri kullanılarak tahmin edilmeye çalışılmıştır. Elde edilen bulgular, TÜFE, Yi-ÜFE ve TARIM-ÜFE arasında istatistiksel olarak anlamlı bir eş-bütünleşme ilişkisinin yanında kısa dönemli nedensellik ilişkilerinin de bulunduğunu işaret etmektedir. Uzun dönemde, TARIM-ÜFE ve YiÜFE'den TÜFE'ye doğru etkinin istatistiksel olarak anlamlı ancak küçük boyutlu olduğu, diğer taraftan TÜFE'den TARIM-ÜFE ve Yi-ÜFE'ye doğru anlamlı ve daha güçlü bir etkinin var olduğu tespit edilmiştir. Bu bulgular ışığında, 2011-2020 yılları arasında Türkiye'de tüketici fiyatları ile üretici fiyatları arasında iki yönlü bir ilişki olduğu, ancak görece tüketici fiyatlarının üretici fiyatlarını daha fazla etkilediği iddia edilebilir.

\section{Analysis of Relationship between the Consumer and Producer Prices in Turkey using Alternative Estimation Methods}

\begin{abstract}
The relationship between consumer prices and producer prices has been discussed in the literature. In this study, the existence and dimensions of the relationship in question for Turkey are examined between the consumer (CPI), the producer (D-PPI), and the agricultural sector (AGR$P P I)$ prices. The stationarity characteristics of time series are examined using five different tests in the study in which the period between January 2011 and June 2020 is covered. The cointegration relationship between the time series is investigated with the standard Johansen, Johansen with structural break, and Lütkepol with structural break, and the short-term dynamics of the relationship are analyzed with the Vector Error Correction model. Unlike the literature, the long-term relationship between time series has been estimated using different estimation methods. The findings indicate that there are statistically significant cointegration relationships between them, as well as short-term causality relationships. In the long run, it is determined that the effect from AGR-PPI and D-PPI to CPI is statistically significant but small in size. On the other hand, the effects from the CPI to AGR-PPI and D-PPI are significant and bigger in size. Considering these findings, it can be claimed that a two-way relationship between producer prices and consumer prices are exist in Turkey for 2011-2020 period, but consumer prices have stronger effect on producer prices.
\end{abstract}

Anahtar Sözcükler: Tüketici Fiyatları, Üretici Fiyatları, Eşbütünleşme, Sistem Denklemleri

JEL: C32, C53, E31, E37

$\begin{array}{ll}\text { Geliş } & : \text { : } 31 \text { Ağustos } 2020 \\ \text { Düzeltme } & : 28 \text { Ekim } 2020 \\ \text { Kabul } & : \text { 04 Aralık 2020 } \\ \text { Tür } & : \text { Araştırma }\end{array}$

Keywords: Consumer Prices, Producer Prices, Cointegration, System Equations

JEL: C32, C53, E31, E37

$\begin{array}{ll}\text { Received } & : 31 \text { August } 2020 \\ \text { Revised } & : 28 \text { October } 2020 \\ \text { Accepted } & : \text { 04 December } 2020 \\ \text { Type } & : \text { Research }\end{array}$

Type : Research 


\section{Giriş}

Ürün piyasasında, üretici ve tüketicilerin etkileşimiyle fiyat olgusu ortaya çıkmaktadır. Ancak ürünün fiyatı üreticiden tüketiciye ulaşma süreci içerisinde farklı eğilimler göstermektedir. Üretici ürettiği ürünün fiyatını belirlerken girdi maliyetleri, önceki dönem talebi ve fiyatı gibi faktörleri dikkate alırken, söz konusu ürünün ulaştırma maliyetleri, stok seviyesi, cari dönem talebi, tüketici davranışları ve ikame malların fiyatı gibi etkiler tüketicinin ürüne ödediği fiyatı etkileyebilmektedir.

Üretici ile tüketici arasındaki zincirde değişen fiyat dinamikleri çeşitli başlıklar altında ölçülmektedir. Yurt İçi Üretici Fiyat Endeksi (Yi-ÜFE), piyasada üretimi yapılan ve yurt içine satışa konu olan ürünlerin üretici fiyatlarındaki değişimi ölçmeyi amaçlamaktadır (TÜiK, 2008). Madencilik ve taş ocakçılığı, imalat ile elektrik, gaz ve su temini sektörlerine göre hesaplanan Yi-ÜFE, yurt içinde üretimi yapılan ürünlerin, dolaylı vergiler hariç peşin satış fiyatını dikkate almaktadır. Tarım Ürünleri Üretici Fiyat Endeksi (TARıM-ÜFE), çiftçinin üreterek piyasaya satışını yaptığı tarım, ormancılık ve balıkçılık ürünlerinin ilk el satış fiyatlarındaki zaman içerisinde meydana gelen değişimi ölçmeye çalışmaktadır (TÜiK, 2008). Yurt Dışı Üretici Fiyat Endeksi (YDÜFE), üretimi ülke içinde yapılan ve ihracata konu olan ürünlerin üretici fiyatlarının zaman içindeki değişimini göstermektedir (TÜiK, 2008). Hizmet Üretici Fiyat Endeksi (HIZMET-ÜFE), hizmetlerin üretici fiyatlarını zaman içindeki fiyat değişimlerini ölçen fiyat endeksidir (TÜiK, 2008). Tüketici Fiyat Endeksi (TÜFE), piyasada tüketime konu olan mal ve hizmetlerin fiyatlarındaki değişimi ölçerek enflasyon oranını hesaplamayı amaçlamaktadır. TÜFE'de vergiler dahil peşin satın alış fiyatları ölçülmektedir ve taksitli satış veya anlaşmalı fiyatlar dikkate alınmamaktadır.

Ürünün tüketiciye ulaştığındaki fiyat TÜFE ile ölçülürken, sanayi sektöründeki üreticinin fiyatı Yi-ÜFE, tarım sektöründeki üreticinin fiyatı TARIM-ÜFE, hizmet sektöründeki üreticinin fiyatı HiZMET-ÜFE ve ihracata konu olan malları üreten üreticinin fiyatı YD-ÜFE ile ölçülmektedir. Her ne kadar tüketici ve üretici fiyatlarını ölçen bu göstergeler arasında çok belirgin tanım ve kapsam farklııkları olsa da fiyat dinamiklerinin anlaşılması açısından aralarındaki ilişki literatürde tartışma konusu olmuştur. Kaynağı açısından talep ve maliyet kökenli olarak ikiye ayrılabilecek enflasyon üzerinde hangi kaynağın daha etkili olduğunun belirlenmesi, para ve/veya maliye politikalarının etkin uygulanması açısından önem taşımaktadır. Literatürde ilişkinin yönü ve boyutu üzerinde bir fikir birliği bulunmamaktadır. Bir görüşe göre, üretici fiyatlarından tüketici fiyatlarına doğru bir nedensellik mevuttur. Bu görüşte girdi maliyetlerindeki değişim önce üretici fiyatlarını, sonrasında ise üretim zincirindeki yayılma etkisiyle birlikte tüketici fiyatlarını etkilemektedir. Tersi görüşte ise herhangi bir nedenden dolayı meydana gelen talep şokunun önce tüketici fiyatlarını sonrasında ise girdilere olan talebi ve girdi maliyetlerini arttıracağı savunulmaktadır. Bunların dışında, iki yönlü ilişkinin var olduğunu iddia eden çalışmalar ve ilişkinin olmadığını öne süren çalışmalar da bulunmaktadır.

Literatürdeki çalışmalarda, genellik üretici ve tüketici fiyatları arasındaki etkileşim iki yönlü analizler kullanılarak (nedensellik ve eşbütünleşme analizleri yardımıyla) analiz edilmiştir. Bu çalışmada ise hem kullanılan verinin kapsamı geniş tutulmuş hem de yöntem olarak daha detaylı bir yaklaşım kullanılmıştır. Üretici fiyatlarının hizmet, tarım ve yurtdışı özelindeki ölçümleri de analize dahil edilirken, bütünleşik bir bakış açısı sağlayan sistem denklemleri yaklaşımına yer verilmiştir. Bu çalışmada tüketici ve üretici fiyatlarının ölçen endekslerin yıllık değişim (enflasyon) oranları arasındaki ilişkinin analizi Ocak 2011-Haziran 2020 dönemi için durağanlık ve eş-bütünleşme analizleri yardımıyla araştırılmıştır. Serilerin durağanlık seviyelerinin daha doğru belirlenebilmesi için, test güçleri açısından farklılık gösteren beş farklı durağanlık testi ile enflasyon oranlarının entegrasyon dereceleri incelenmiştir. Sonrasında, aralarındaki uzun dönemli ilişki vektör otoregresif (VAR) modeline dayalı Johansen eş-bütünleşme testi ile incelenmiş ve kısa dönemli dinamikler vektör hata düzeltme (VEC) modeli yardımıyla incelenmiştir. Bu çalışmada literatürden farklı olarak, yıllık enflasyon oranları arasındaki uzun dönem ilişki sistem denklemleri çerçevesinde ele alınmış ve iki aşamalı en küçük kareler (2AEKK), üç aşamalı en küçük kareler (3AEKK) ve görünürde ilişkisiz regresyon (SUR) yöntemleri kullanılmıştır. Söz konusu tahmin yöntemlerinden elde edilen uzun dönem katsayılar ve VEC modelinin ima ettiği uzun dönem katsayıları birlikte dikkate alınarak yıllık enflasyon oranlarının uzun dönemli ilişkileri değerlendirilmiştir. 
Fiyat endeksleri arasındaki ilişki ile ilgili literatürde yapılan önceki çalışmalar ikinci bölümde incelemiştir. Kullanılan veriler ve yöntem, çalışmanın üçüncü bölümünde açıklanmıştır. Dördüncü bölümde ampirik sonuçlar sunulmuş ve son bölümde çalışmanın bulguları genel olarak değerlendirilmektedir.

\section{Literatür}

Tüketici fiyatları ile üretici fiyatları arasındaki ilişki literatürde tartışılagelen bir konudur. Ancak, ilişkinin yönü ve varlığı konusunda bir fikir birliği bulunmamaktadır. Iliş̧inin olmadığını savunan çalışmaların yanı sıra, tek ya da çift yönlü ilişkinin bulunduğunu savunan çalışmalar bulunmaktadır.

Literatürde, üretici fiyatlarıyla tüketici fiyatları arasında ilişki olmadığını öne süren az sayıda çalışma bulunmaktadır. Örneğin, Clark (1995) ve Blomberg ve Harris (1995) tarafından yapılan çalışmalarda, üretici fiyatları ile tüketici fiyatları arasında bir ilişkinin Amerika Birleşik Devletleri (ABD) için geçerli olmadığı iddia edilmiştir.

Tüketici fiyatları ile üretici fiyatları arasında en az tek yönlü bir ilişkinin olduğunu savunan çalışmalar ise literatürde çoğunluktadır. Tiwari (2012), Avustralya için tüketici fiyatlarından üretici fiyatlarına doğru bir ilişkinin olduğunu, M. Shahbaz, Tiwari ve Tahir (2012) aynı ilişkinin Pakistan için, Tiwari ve Shahbaz (2013) ise Hindistan için geçerli olduğunu göstermiştir. Sui ve Yuerong (2019) yaptığı çalışmada Çin ekonomisinde fiyat endeksleri arasındaki ilişkinin zamana bağlı olarak değiştiğini, ancak tüketici fiyatlarının üretici fiyatlarını etkilediği dönemlerin ters yönde etkinin hâkim olduğu dönemlere kıyasla daha uzun sürdüğünü tespit etmiştir.

Tiwari, Suresh, Arouri ve Teulon (2014) Meksika ekonomisinde iki yönlü bir fiyat ilişkisinin olduğunu iddia ederken; Topuz, Yazdifar ve Sahadev (2018) çalışması Türkiye ve İngiltere'de iki yönlü ilişki olduğunu savunmaktadır. Tiwari, Mutascu ve Andries (2013) tarafından yapılan çalışmada, Romanya ekonomisinde farklı zaman aralıklarında farklı yönde ilişkilerin olduğunu öne sürümüşlerdir. Diğer bir ifadeyle iki yönlü nedensellik olduğunu ileri sürmüştür.

Akçay (2011) tarafından yapılan çalışmada elde edilen sonuçlara göre, üretici fiyat endeksi ile tüketici fiyat endeksi arasındaki nedensellik ilişkisi, Finlandiya ve Fransa'da üretici fiyat endeksinden tüketici fiyat endeksine doğru iken, Almanya'da çift yönlüdür. İsveç ve Hollanda örneğinde ise istatistiksel olarak anlamlı bir nedensellik tespit edilmemiştir.

Literatürde Türkiye için yapılan Akdi, Berument ve Cilasun (2006), Şahinöz, Demirhan ve Coşar (2007), Zortuk (2008), Yamak ve Topbaş (2008), Saraç ve Karagöz (2010), Abdioğlu ve Korkmaz (2012), Erdem ve Yamak (2014), Yıldırım (2015), Terzi ve Tütüncü (2017), Saatçioğlu ve Karaca (2017) ve Öner (2018) çalışmalarına erişilebilmiştir.

Akdi, Berument ve Cilasun (2006) çalışmasında 1987-2004 dönemi için kısa dönemde tüketici fiyatları ile üretici fiyatları beraber hareket ettiği, uzun dönem de ilişkisiz olduğu iddia edilmektedir. Şahinöz, Demirhan ve Coşar (2007), tüketici fiyat endeksleri ile üretici fiyat endeksleri arasındaki tanım ve kapsam farklııklarından dolayı ilişkinin kurulamayacağını ve farklı yollar izlenmesi gerektiğini öne sürmüştür.

Zortuk (2008), 1986-2004 dönemi için tüketici fiyatlarından üretici fiyatlarına doğru bir ilişkinin mevcut olduğu sonucuna ulaşırken, Yamak ve Topbaş (2008) tarafından yapılan analizde 1982-2005 dönemi için üretici fiyatlarının tüketici fiyatlarına doğru bir ilişkinin olduğunu ileri sürmüştür. Saraç ve Karagöz (2010) ise 1994-2009 dönemi için üretici fiyatlarından tüketici fiyatlarına doğru hem kısa hem de uzun dönemde ilişkinin olduğunu belirlemiştir.

Abdioğlu ve Korkmaz (2012) tarafından 2003-2012 dönemi için yapılan analiz sonucunda, çift yönlü nedensellik ilişkisi olduğu gösterilmiştir. Çalışmada, giyim ve konut sektörlerinde tüketici fiyatlarından üretici fiyatlarına doğru tek yönlü bir nedensellik ilişkisi olduğu belirlenmiştir. Erdem ve Yamak (2014) ise 1987-2012 dönemi için zamana bağlı değişen parametrelere imkân veren Kalman filtre yöntemi ile tahmin ettikleri regresyon modeli çerçevesinde, üretici fiyatlarından tüketici fiyatlarına olan nedenselliğin 2003 yılı sonrasında azaldığını iddia etmektedirler. 
Yıldırım (2015) yapmış olduğu çalışmada 1987-2013 dönemi için yüksek enflasyon dönemlerinde üretici ve tüketici fiyatları arasındaki ilişkinin arttığını, düşük enflasyon dönemlerinde ise ilişkinin azaldığını iddia etmektedir. Terzi ve Tütüncü (2017), 2010-2016 dönemi için yaptıkları analiz sonucunda hem kısa hem de uzun dönemde çift yönlü nedensellik ilişkisinin olduğu tespit edilmiştir. Saatçioğlu ve Karaca (2017), 20052016 dönemi için üretici fiyatlarından tüketici fiyatlarına doğru bir nedensellik olduğunu ileri sürerken, Öner (2018) ise 2004-2016 dönemi için tersi yönde bir nedensellik olduğunu savunmaktadır.

\section{Veri ve Yöntem}

Çalışmada analiz edilen veri; Türkiye'nin tüketici ve üretici fiyatlarını ölçen TÜFE, Yi-ÜFE, YD-ÜFE, TARIM-ÜFE ve HIZMET-ÜFE endekslerinin bir önceki yılın aynı ayına göre değişimini gösteren yıllık değişim (enflasyon) oranlarıdır. Fiyat endekslerinin seviyelerinin genel olarak 2. dereceden fark durağan olması, ekonometrik modellerde gerek tahminci varsayımlarının sağlanmasında gerekse katsayı tahminlerinin yorumlanmasında zorluklara neden olabilmektedir. Veri setinde,

- Tüketici Fiyatları Endeksi- Bir önceki yılın aynı ayına göre değişim $\left(\pi_{t, T U ̈ F E}\right)$,

- Tarım Ürünleri Üretici Fiyat Endeksi - Bir önceki yılın aynı ayına göre değişim $\left(\pi_{t, T A R I M-U ̈ F E}\right)$,

- Yurt içi ÜFE - Bir önceki yılın aynı ayına göre değişim $\left(\pi_{t, Y \dot{I}-U ̈ F E}\right)$,

- Yurt Dışı Üretici Fiyat Endeksi - Bir önceki yılın aynı ayına göre değişim $\left(\pi_{t, Y D-U ̈ F E}\right)$,

- Hizmet Üretici Fiyat Endeksi - Bir önceki yılın aynı ayına göre değişim $\left(\pi_{t, H i z M E T-U ̈ F E}\right)$,

değişkenleri bulunmaktadır. Parantez içinde verilen semboller, endekslerin yıllık enflasyon oranlarını temsil etmek üzere çalışmada kullanılmıştır. $\pi_{t}$ 'ler için analiz dönemi olarak 2011:01-2020:06 aralığı belirlenmiştir. 2008-2009 yılında yaşanan küresel ekonomik krizin araştırılan ilişki üzerindeki bozucu etkisini dışlamak için 2011 ve sonrası dönem seçilmiştir. Veri, Türkiye İstatistik Kurumu (TÜiK)'nun Fiyat Endeksleri veri tabanından alınmıştır. Söz konusu veri setinde TRAMO/SEATS (Gomez ve Maravall, 1998) ile yapılan analiz sonucunda anlamlı mevsimsellik tespit edilememiştir. Tablo $1^{\prime}$ de çalışmada kullanılan veriye ilişkin tanımlayıcı istatistikler verilmiştir. Tabloya bakıldığında $\pi_{t, H i z M E T-U ̈ F E}$ 'nin gözlem sayısının oldukça az olduğu göze çarpmaktadır. HiZMET-ÜFE endeksi, 2015=100 temel yıllı olup 2017 yılı itibarıyla Tüik tarafından yayımlanmaya başlamıştır. $\pi_{t, H i Z M E T-U ̈ F E}$ yeterli gözlem sayısına sahip olmadığı için analiz dışı bırakılmıştır. TARIM-ÜFE ve YD-ÜFE serilerinin negatif değerler aldığı gözlemlenmekte ve ortalama olarak analiz döneminde TÜFE \%10, Yi-ÜFE \%11 ve HiZMET-ÜFE'nin \%16 değer aldığı gözlemlenmektedir.

Tablo 1. Tanımlayıcı İstatistikler

\begin{tabular}{|c|c|c|c|c|c|}
\hline & $\tau_{t, T \cup ̈ F E}$ & $\pi_{t, T A R I M-U ̈ F E}$ & $\pi_{t, Y \mathrm{I}-\ddot{U} F E}$ & 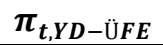 & $\boldsymbol{\pi}_{t, H \mathrm{I} Z M E T-U ̈ F E}$ \\
\hline Gözlem sayısı & 114 & 114 & 114 & 114 & 30 \\
\hline Minimum & 0,040 & $-0,076$ & 0,017 & $-0,112$ & 0,064 \\
\hline Maksimum & 0,252 & 0,308 & 0,461 & 0,750 & 0,310 \\
\hline Ortalama & 0,101 & 0,094 & 0,112 & 0,142 & 0,162 \\
\hline
\end{tabular}

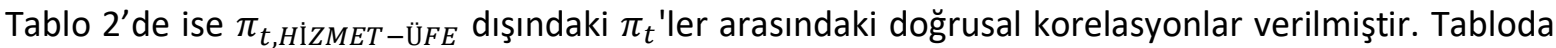
üretici fiyatlarını temsil eden $\pi_{t, Y \dot{I}-U ̈ F E}$ ve $\pi_{t, Y D-U ̈ F E}$ arasındaki ilişkinin $\% 90$ 'ın üzeride olduğu gözlemlenmektedir. Yi-ÜFE fiyat endeksi yurt içindeki üreticilerin fiyatlama davranışlarını ölçerken, YD-ÜFE ise ihracat yapan üreticilerin fiyatlama davranışlarını ölçmeyi amaçlamaktadır. Bu iki değişken arasında yüksek korelasyon bulunması, yurtiçi piyasa üretim yapan üreticiler ile ihracat yapan üreticiler arasında fiyatlama davranışı açısından bir fark olmadığını göstermektedir. Dolayısıyla, Yi-ÜFE için yapılacak tüm yorumlar aynı zamanda YD-ÜFE için de geçerli hale gelmektedir. Tüketici fiyatları ile üretici fiyatları arasındaki kurulacak bir modelde bu iki değişkenin denklemin sağ tarafında bulunması tama yakın çoklu doğrusal bağıntı sorununu beraberinde getirecektir. Bu nedenle, $\pi_{t, Y \dot{I}-\ddot{U} F E}$ analize dahil edilirken, $\pi_{t, Y D-U ̈ F E}$ analiz dışında bırakılmıştır. 
Tablo 2. Korelasyon Katsayıları

\begin{tabular}{|c|c|c|c|c|}
\hline & $T \ddot{U} F E$ & $\pi_{t, T A R I M-U ̈ F E}$ & $\pi_{t, Y \dot{I}-U ̈ F E}$ & $\pi_{t, Y D-U ̈ F E}$ \\
\hline$\pi_{t, T \mathrm{ÜFE}}$ & 1 & - & - & - \\
\hline$\pi_{t, T A R I M-U ̈ F E}$ & 0,617 & 1 & - & - \\
\hline$\pi_{t, Y \dot{I}-\ddot{U} F E}$ & 0,886 & 0,54 & 1 & - \\
\hline$\pi_{t, Y D-\ddot{U} F E}$ & 0,741 & 0,376 & 0,904 & 1 \\
\hline
\end{tabular}

Bu çalışmada öncelikle $\pi_{t}$ 'lerin entegrasyon (durağanlık) dereceleri belirlenmiştir. Zaman serisinin ortalaması ve varyansının zamana bağlı olarak değişmediği ve iki dönem arasındaki ilişkinin sadece uzaklığa bağlı olduğu seviyesi "durağan olduğu seviye" olarak kabul edilmektedir (Gujarati, 2009). I(0) ifadesi, seviyesinde durağanlığı ifade ederken, I(1) birinci farkında durağanlığı ifade etmektedir. $\pi_{t, T U ̈ F E}$, $\pi_{t, T A R I M-U ̈ F E}$ ve $\pi_{t, Y \dot{I}-U ̈ F E}$ arasında kısa ve uzun dönemli ilişkilerin belirlenmesi sırasında Granger ve Newbold (1974) tarafından vurgulanan sahte regresyon sorunuyla karşılaşmamak için $\pi_{t}{ }^{\prime}$ lerin entegrasyon derecesinin belirlenmesi önemlidir. Bu amaçla literatürde sıkça başvurulan beş farklı test kullanılmıştır. Bu testler, ADF (Dickey ve Fuller, 1981), PP (P. Phillips ve Perron, 1988), ERS (Elliott, Rothenberg ve Stock, 1996), KPSS (Kwiatkowski vd., 1992) ve Zivot-Andrews (Zivot ve Andrews, 1992) durağanlık testleridir.

ADF testi boş hipotezinde serinin durağan olmadığını sınamaktadır. Test denklemindeki olası otokorelasyon problemi, ADF testinde uygun gecikme uzunluğu belirlenerek giderilirken, PP testinde parametrik olmayan bir yaklaşımla (HAC) test denklemindeki otokorelasyon ve değişen varyans problemi çözülmektedir. Diğer taraftan PP testinin en önemli dezavantajı is asimptotik teoriye dayanması ve kısa zaman serilerinde söz konusu HAC düzeltmesinin geçersiz olmasıdır. ADF ve PP testleri yapısal kırılmalara karşı hassas olup ve küçük örneklerde zayıf test gücüne sahiptirler. ERS testinde ise ADF test denklemi kullanılır ancak seriyi doğrusal trendden zamana bağı̆ı değişen bir ortalama yaklaşımıyla olarak arındırır. Böylece test gücü açısından ERS testi ADF testinden üstündür. KPSS testi diğer testlerden farklı olarak boş hipotezde serinin durağan olduğunu sınamaktadır ve bu şekilde test gücü açsısından ADF testinin daha gelişmiş bir versiyonudur. Zivot-Andrews testi, yapısal kırılmalara karşı hassasiyet açısından diğer testlere kıyasla daha güçlü bir durağanlık testidir. Bu teste seride tek bir yapısal kırılmaya izin verilmekte ve ADF testindeki tistatistiğinin minimum yapan gözlem kırılmanın yaşandığı gözlemdir. Zivot-Andrews testi hipotez yapısı olarak ADF, PP ve GLS ile aynıdır.

Bu çalışmada, fiyat endekslerinin entegrasyon dereceleri belirlendikten sonra aralarındaki uzun dönemli ilişkiyi belirlemek amacıyla Vektör Otoregresif (VAR) modeline dayalı Johansen eş-bütünleşme testi (Johansen 1991) uygulanmıştır. Testin ilk aşamasında (1) numaralı eşitlikte ifade edilen bir VAR modeli tahmin edilir.

$$
X_{t}=\Pi 1 X_{t-1}+\cdots+\Pi_{k} X_{t-k}+\mu+\Phi D_{t}+\varepsilon_{t}, \quad(t=1, \ldots, T)
$$

$X \pi_{t}$ 'lerden oluşan veri matrisini, $D$ ise dışsal değişkenleri ve $\varepsilon$ modelin hata terimlerini göstermektedir. VAR modelinin uygun gecikme uzunluğu $(k)$ Akaike, Hannan-Quinn ve Schwarz bilgi kriterleri dikkate alınarak belirlenmiştir. Bu kriterlerin önerdiği gecikme uzunluklarından otokorelasyon problemi olmayan gecikme uzunluğu seçilmiştir. VAR modeli tahmininden sonra (2) numaralı eşitlikte ifade edilen VEC modeli tahmin edilir.

$$
\begin{array}{r}
\Delta X_{t}=\Gamma_{1} \Delta X_{t-1}+\cdots+\Gamma_{k-1} \Delta X_{t-k+1}+\Pi X_{t-k}+\mu+\Phi D_{t}+\varepsilon_{t}(\text { VEC Modeli }) \\
\Gamma_{i}=-\left(I-\Pi_{1}-\cdots-\Pi_{i}\right)(i=1, \ldots, k-1) \\
\Pi=-\left(I-\Pi_{1}-\cdots-\Pi_{k}\right)
\end{array}
$$

$\Gamma_{i}$ matrisleri uzun dönemli etkileri barındırmaktadır. Diğer taraftan, $X$ matrisindeki değişkenlerde yapısal kırılma olduğu durumda, Johansen testinin gücü zayıflamaktadır (Lütkepohl, Saikkonen ve Trenkler, 
2004). Lütkepohl, Saikkonen ve Trenkler (2004) çalışmasında bilinmeyen bir zamanda yapısal kırılmanın tanımlandığı VAR modeline dayalı bir eş-bütünleşme testi önerilmiştir. Bu çalışmada hem Johansen (1991), hem Lütkepohl, Saikkonen ve Trenkler (2004) tarafından önerilen eş-bütünleşme testleri hem de Johansen (1991) testinin 2018 yılı Haziran ayındaki aykırı değeri temsilen bir kukla değişken (eğer $t>=2018$ Haziran ise $D_{t}=1$, değilse 0 ) ile genişletilen versiyonu kullanılarak $\pi_{t}{ }^{\prime}$ ler arasındaki eşbütünleşme ilişkisi test edilmiştir.

Eş-bütünleşme vektörü sayısının ( $r$ ) sıfıra eşit olduğu boş hipotezi $(r=0),(2)$ numaralı modelden elde edilen iz-test istatistiği kullanılarak test edilir. Eğer boş hipotez reddedilirse, eş-bütünleşme vektörü sayısının birden büyük olduğu $(r \geq 1)$ boş hipotezi test edilir. Bu süreç $X$ matrisindeki değişken sayısının bir eksiğine kadar devam eder. Lütkepol testi için kritik değerler Trenkler (2003) çalışmasından alınırken, Johansen testi için kritik değerler Osterwald-Lenum (1992) çalışmasından alınmıştır.

$\pi_{t}{ }^{\prime}$ ler arasındaki eş-bütünleşme vektörü sayısı belirlendikten sonra, nihai bir VEC modeli tahmin edilerek kısa dönemli dinamikler araştııılmıştır. Tahmin edilen VEC modelinde otokorelasyon ve değişen varyans probleminin varlığı Breusch-Godfrey otokorelasyon testi ve Breusch-Pagan değişen varyans testi ile araştırılmıştır. VEC model yapısı içinde $\pi_{t}$ 'ler arasındaki Granger nedensellik ilişkilerini tespit etmek için Wald testi uygulanmıştır.

$\pi_{t}{ }^{\prime}$ ler arasındaki kısa dönemli etkileşimleri daha detaylı analiz etmek amacıyla Lütkepohl (2005) çalışmasında önerildiği gibi, tahmin edilen VEC modelinin dayandığı VAR modeli kullanılarak etki-tepki fonksiyonları ve öngörü hatasının varyans ayrıştırma analizleri uygulanmıştır. Etki-tepki fonksiyonu analizi, VAR modelinin hareketli ortalamalar gösteriminden elde edilen ortogonal katsayılar kullanılarak yapılır. Bu çalışmada kümülatif olarak ve \%95 güven aralıkları içinde sunulmuştur. Etki tepki fonksiyonları, sistemdeki bir değişkendeki beklenmedik bir şoka karşı diğer değişkenlerin gösterdiği tepkileri ölçmektedir. Öngörü hatasının varyansının ayrıştırması analizi ise değişken bazında elde edilen ortogonal etki-tepki katsayılarının değişkenlerin öngörü hatasının varyansına katkılarını göstermektedir. Böylece, sistemdeki bir değişkenin öngörü hatasının varyansına diğer değişkenlerin katkıları yorumlanabilmektedir.

Bu çalışmada, kısa dönemli etkiler analiz edildikten sonra uzun dönemli etkilerin araştırılmasında farklı tahmin yöntemleri denenmiştir. Klasik yaklaşımda, VEC modeline dayalı kısa dönemli analizler yapıldıktan sonra yine VEC modelinin ima ettiği uzun dönem katsayılar yorumlanmaktadır. VEC modelindeki katsayılardan uzun dönem katsayıların elde edilmesi sürecinde hata düzeltme terimleri kullanılırken (Pesaran, Shin ve Smith, 2001), katsayıların standart hataları ise Oehlert (1992) tarafından önerilen yaklaşımla hesaplanmaktadır. Bu çalışmada, klasik yaklaşıma ek olarak $\pi_{t}$ 'ler arasındaki uzun dönemli ilişki katsayıları sistem denklemi yaklaşımı dahilinde tahmin edilmeye çalışılmıştır. Öncelikle (3) numaralı eşitlikte verildiği şekilde bir sistem kurulmuştur.

$$
\begin{aligned}
& \pi_{t, T \ddot{U} F E}=\beta_{1}+\alpha_{1,1} \pi_{t, T A R I M-U ̈ F E}+\alpha_{1,2} \pi_{t, Y I-\ddot{U} F E}+v_{1, t} \\
& \pi_{t, T A R I M-\ddot{U} F E}=\beta_{2}+\alpha_{2,1} \pi_{t, T U ̈ F E}+\alpha_{2,2} \pi_{t, Y I-U ̈ F E}+v_{2, t} \\
& \pi_{t, Y I-U ̈ F E}=\beta_{3}+\alpha_{3,1} \pi_{t, T A R I M-U ̈ F E}+\alpha_{3,2} \pi_{t, T U ̈ F E}+v_{3, t}
\end{aligned}
$$

$\mathrm{i}=1,2,3$ olmak üzere, $\beta_{i}$ modelin sabit terimini, $\alpha$ değişken katsayılarını, $v_{i, t}$ ise i. denklemin hata terimini göstermektedir. Klasik yaklaşımda (3) numaralı eşitlikte verilen sistem En Küçük Kareler (EKK) tahmincisi kullanılarak tahmin edilebilir. Ancak, sistemdeki modellerde içsel bağıntı problemi olması durumunda EKK tahmincisi sapmalı ve tutarsız sonuçlar üretmektedir. Bu durumda, EKK yönteminin geliştirilmiş versiyonu olan iki Aşamalı en küçük kareler (2AEKK) tahmincisinin kullanılması önerilir. Sistemdeki modellerin 2AEKK tahmincisi ile tahmininden elde edilen hata terimleri arasındaki kovaryans $\left(E\left(v_{i, t}, v_{j, t}\right)\right)$ nedeniyle tutarsız olması durumunda Üç Aşamalı En Küçük Kareler (3AEKK) tahmincisi kullanılır. Bu yöntemde, $E\left(v_{i, t}, v_{j, t}\right)$ 'lerden oluşan diagonal bir matris, katsayı tahmininde ağırlık olarak kullanılır. Böylelikle, sistemdeki $\alpha_{i, i}$ tahminlerinin tutarlı olması sağlanır (Zellner ve Theil, 1962). 2AEKK ve 3AEKK tahmin yöntemlerinden hangisinin kullanılacağına Hausman testi ile karar verilebilir (Hausman, 1978). Testin boş hipotezi, sistemdeki tüm araç değişkenlerin hata terimleri ile ilişkisiz olduğunu iddia etmektedir. Bu 
hipotez altında, 2AEKK ve 3AEKK tahmin yöntemlerinin ikisi de tutarlıdır ancak 3AEKK yöntemi asimptotik olarak etkindir. Eğer boş hipotez reddedilirse, 2AEKK tahmincisi tutarlı ancak 3AEKK yöntemi tutarsızdır.

Araç değişken olarak model hata terimleriyle ilişkisiz ancak bağımsız değişkenler ile ilişkili değişkenler seçilmelidir. Araç değişken olarak, bağımsız değişkenlerin 1 ve 2. gecikmeleri ile YD-ÜFE değişkeni kullanılmıştır. Hausman test istatistiği $(m) m=\left(\beta_{2 A E K K}-\beta_{3 A E K K}\right)^{\prime}\left(V_{2 A E K K}-V_{3 A E K K}\right)\left(b_{2 A E K K}-b_{3 A E K K}\right)$ şeklinde hesaplanmaktadır. $b_{2 A E K K}$ ve $V_{2 A E K K}, 2 A E K K$ tahmininden elde edilen katsayı tahminleri ve onların varyans-kovaryans matrislerini, $b_{3 A E K K}$ ve $V_{3 A E K K}$ ise $3 A E K K$ tahmininden elde edilen katsayı tahminleri ve onların varyans-kovaryans matrislerini temsil etmektedir. Ancak, 3AEKK tahmin yönteminde $v_{i, t}$ 'ler arasında ilişki olmadığı $\left(E\left(v_{i, t}, v_{j, t}\right) \neq 0\right)$ varsayılır. Bu varsayım ihlal edildiğinde, 2AEKK ve 3AEKK tahminleri sapmalı ve tutarsızdır. Bu durumda, Görünürde iliş̧kisiz Regresyon (SUR) modelleri kullanılır (Zellner, 1962). SUR modelleri sistemdeki modellerin hata terimleri arasındaki ilişkiyi dikkate alarak katsayı tahminlerini elde eder. Bu çalışmada, $\pi_{t}{ }^{\prime}$ ler arasındaki uzun dönemli ilişkiyi temsil eden katsayıların analizinde hem VEC modellerinin ima ettiği katsayılar hem de (3) numaralı sistemin EKK, 2AEKK, 3AEKK ve SUR yöntemlerinde elde edilen $(\alpha)$ katsayılar dikkate alınarak, tüketici ve üretici fiyat endeksleri arasındaki ilişki tanımlanmaya çalışılmıştır.

\section{Bulgular}

$\pi_{t, T U ̈ F E}, \pi_{t, T A R I M-U ̈ F E}$ ve $\pi_{t, Y \dot{I}-\ddot{U} F E}$ arasındaki ilişkinin analiz edildiği bu çalışmada, entegrasyon derecelerinin belirlenmesi için yapılan durağanlık testlerinin sonuçları Tablo 3'te özetlenmiştir. Tablo 3'te verilen test sonuçlarına göre, $\pi_{t}$ 'lerin sevieyelerinde durağan olmadığını yani I(1) iddia eden boş hipotezin $\pi_{t, T U ̈ F E}$ ve $\pi_{t, Y \dot{I}-U ̈ F E}$ için güçlü bir şekilde reddedildiği, $\pi_{t, T A R I M-U ̈ F E}$ için ise durumun testler arasında farklılık gösterdiği anlaşılmaktadır. $\pi_{t, T A R I M-U ̈ F E}$ serisi için eski nesil testler (ADF ve PP) boş hipotezi reddederken, ERS, KPSS ve Zivot-Andrews gibi yeni nesil testler boş hipotezi reddedememiştir. Testlerin gücünün nesiller arasında arttığı varsayımıyla yeni nesil testlerin sonuçlarına göre tercih yapılmış ve $\pi_{t, T A R I M-U ̈ F E}$ serisinin I(1) olduğuna karar verilmiştir. Nitekim, $\Delta \pi_{t}$ 'lerin durağan olmadığını yani I(2) olduğunu iddia eden boş hipotezin tüm değişkenler için reddedilmiştir. Dolayısıyla $\pi_{t, T u ̈ F E}, \pi_{t, T A R I M-U ̈ F E}$ ve $\pi_{t, Y \dot{I}-U ̈ F E}$ değişkenlerinin birinci farkında durağan yani I(1) olduğu sonucuna varılmıştır.

$\pi_{t}{ }^{\prime}$ lerin I(1) seviyesinde durağan olduğunun belirlenmesinden sonra Johansen eşbütünleşme testi için VAR modeli üzerinden uygun gecikme uzunluğu belirlenmiştir. Gecikme uzunlukları için bilgi kriterlerinden elde edilen sonuçlar Tablo 4'te sunulmuştur. Tablo 4'e göre AIC ve HQ kriterleri 3 gecikmeyi önerirken SC kriteri 2 gecikmeyi önermektedir. Bu çalışmada, VAR modeli için gecikme uzunluğu $k$, kriterlerin çoğunluğunun önermesiyle 3 olarak alınmıştır.

2 gecikmeli $(k-1)$ VEC modeli kullanılarak I(1) entegrasyon derecesine sahip $\pi_{t}$ 'lere 3 farklı eşbütünleşme testi uygulanmıştır. Bunlar, klasik Johansen, bilinmeyen tarihli yapısal kırılmalı Lütkepol ve 2018-Haziran tarihli yapısal kırılmalı Johansen testleridir. "2018 Haziran" tarihi klasik Johansen eş bütünleşme testinden elde edilen hata terimlerinin analizi sonucunda tespit edilmiştir. Tablo 5 'te eşbütünleşme test sonuçları verilmiştir. Değişkenler arasındaki eş bütünleşme ilişkisinde trendin var olmadığı ve sabit bir terim olduğu varsayımıyla sabitli ve trendsiz spesifikasyon seçilmiştir. Diğer taraftan spesifikasyon seçiminin sonuçları etkilemediği görülmüştür. $r$ eşbütünleşme verktörü sayısını göstermektedir.

Sonuçlara bakıldığında, tüm test tiplerinde $r=0$ ve $r>=1$ boş hipotezlerinin reddedildiği görülmektedir. Bu bulgu $\pi_{t, T U ̈ F E}, \pi_{t, T A R I M-U ̈ F E}$ ve $\pi_{t, Y \dot{I}-U ̈ F E}$ arasında en az iki adet eşbütünleşme vektörü olduğuna işaret etmektedir. Diğer bir ifadeyle $\pi_{t, T U ̈ F E}, \pi_{t, T A R I M-U ̈ F E}$ ve $\pi_{t, Y \dot{I}-\ddot{U} F E}$ arasında en az iki uzun dönemli ilişki mevcut olduğu anlaşılmaktadır. Diğer taraftan, yapısal kırılmalı testlerin alternatifine göre boş hipotezleri daha güçlü bir şekilde reddettiği görülmektedir. 2018 yılı Haziran ayında meydana gelen dışsal etkiyi eşbütünleşme testinde dikkate almanın $\pi_{t}$ 'ler arasındaki uzun dönemli ilişkiyi tespit etmeye katkı sağladığı görülmektedir. 


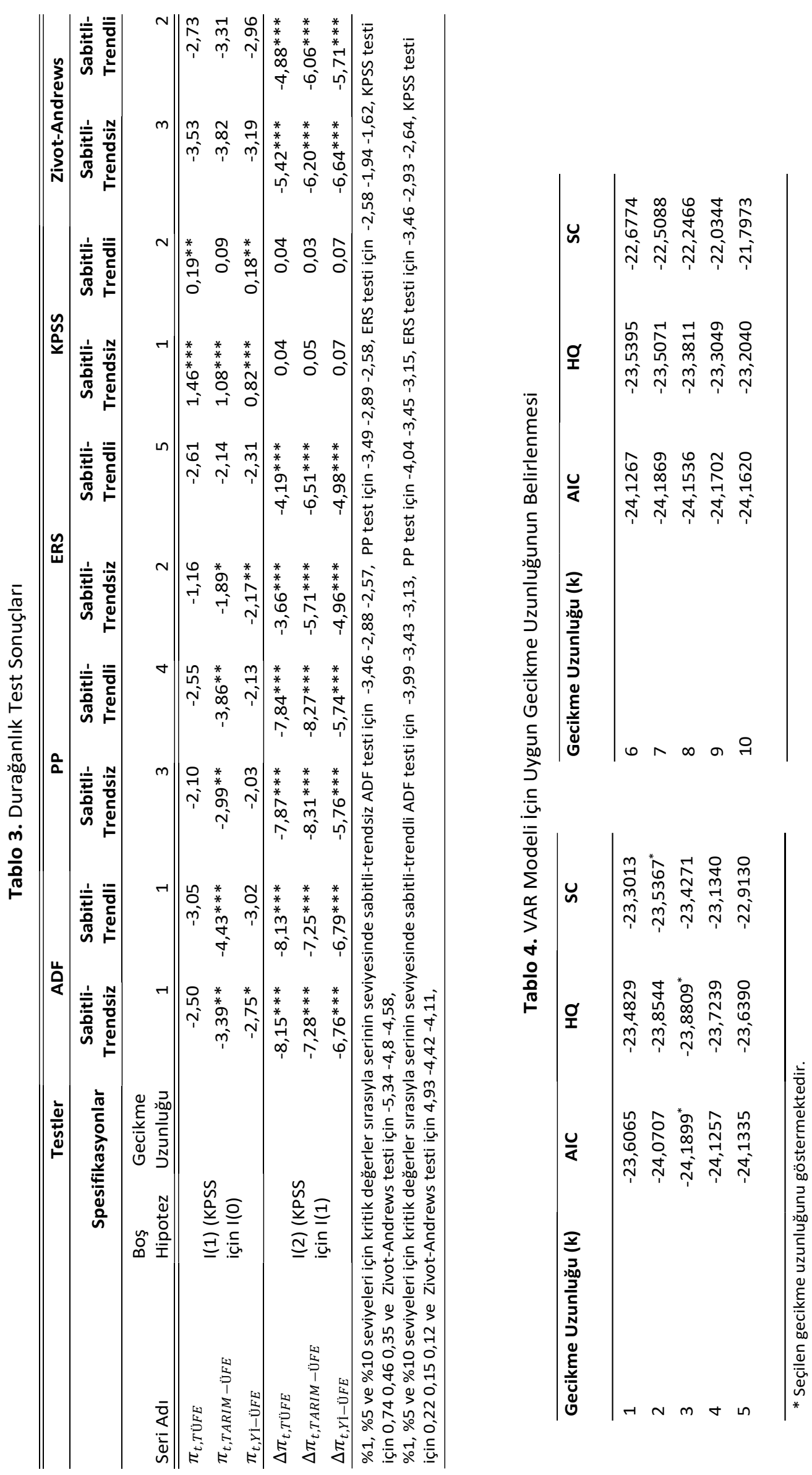


Tablo 5. Eşbütünleşme Analizi Sonuçları

\begin{tabular}{llrrrr}
\hline Test Tipi & $\begin{array}{l}\text { Boş } \\
\text { hipotez }\end{array}$ & $\begin{array}{r}\text { iz-Test } \\
\text { istatistiği }\end{array}$ & $\begin{array}{r}\text { \%10 } \\
\text { Kritik } \\
\text { Değer }\end{array}$ & $\begin{array}{r}\text { \%5 } \\
\text { Kritik } \\
\text { Değer }\end{array}$ & $\begin{array}{r}\text { Kritik } \\
\text { Değer }\end{array}$ \\
\hline Sabitli ve trendsiz & $r<=2$ & 6,73 & 7,520 & 9,240 & 12,970 \\
Sabitli ve trendsiz & $r<=1$ & $21,97^{* *}$ & 17,850 & 19,960 & 24,600 \\
Sabitli ve trendsiz & $r=0$ & $50,19^{* * *}$ & 32,00 & 34,910 & 41,070 \\
Sabitli ve trendsiz + Bilinmeyen yapısal kırılmalı & $r<=2$ & $4,785^{* *}$ & 3,00 & 4,120 & 6,890 \\
Sabitli ve trendsiz + Bilinmeyen yapısal kırılmalı & $r<=1$ & $23,586^{* * *}$ & 10,450 & 12,280 & 16,420 \\
Sabitli ve trendsiz + Bilinmeyen yapısal kırılmalı & $r=0$ & $48,481^{* * *}$ & 21,800 & 24,280 & 29,470 \\
Sabitli ve trendsiz + 2018-Haziran yapısal kırılmalı & $r<=2$ & 5,821 & 7,520 & 9,240 & 12,970 \\
Sabitli ve trendsiz + 2018-Haziran yapısal kırılmalı & $r<=1$ & $29,781^{* * *}$ & 17,850 & 19,960 & 24,600 \\
Sabitli ve trendsiz + 2018-Haziran yapısal kırılmalı & $r=0$ & $69,783^{* * *}$ & 32,00 & 34,910 & 41,070 \\
\hline & & & & &
\end{tabular}

Sonuç olarak, aynı entegrasyon derecesindeki I(1) $\pi_{t, T U ̈ F E}, \pi_{t, T A R I M-U ̈ F E}$ ve $\pi_{t, Y \dot{I}-U ̈ F E}$ arasında uzun dönemli bir ilişkinin mevcut olduğu ve iki adet eşbütünleşme vektörü ile bu ilişkinin temsil edildiği görülmüştür.

Eşbütünleşmenin var olduğu varsayımı altında, $\pi_{t, T U ̈ F E}, \pi_{t, T A R I M-U ̈ F E}$ ve $\pi_{t, Y \dot{I}-\ddot{U} F E}$ arasında $k=3$ ve sabit terimli bir VAR(3) modeli tahmin edilmiş ve bu model kullanılarak etki-tepki fonksiyonları ve öngörü hatasının varyans ayrıştırma analizleri yapılmıştır. Etki-tepki fonksiyonlarına ilişkin elde edilen sonuçlar Şekil 1'de özetlenmiştir.

Şekil 1'de $3 \times 3$ boyutunda bir grafik kümesi bulunmaktadır. Birinci sütunda bulunan üç grafik, $\pi_{t, T U ̈ F E}, \pi_{t, T A R I M-U ̈ F E}$ ve $\pi_{t, Y \dot{I}-U ̈ F E}$ 'de meydana gelen bir standart sapmalık şoka karşı $\pi_{t, T U ̈ F E}$ 'nin vereceği tepkileri göstermektedir. İinci sütunda buluna üç grafik $\pi_{t, T U ̈ F E}, \pi_{t, T A R I M-U ̈ F E}$ ve $\pi_{t, Y \dot{I}-U ̈ F E}$ 'de meydana gelen bir standart sapmalık şoka karşı $\pi_{t, T A R I M-U ̈ F E}$ 'nin vereceği tepkileri gösterirken, son sütunda bulunan üç grafik ise $\pi_{t, T U ̈ F E}, \pi_{t, T A R I M-U ̈ F E}$ ve $\pi_{t, Y \dot{I}-\ddot{U} F E}$ 'de meydana gelen bir standart sapmalık şoka karşı $\pi_{t, Y \dot{I}-U ̈ F E}$ 'nin vereceği tepkileri göstermektedir. Elde edilen sonuçlar, $\pi_{t, T A R I M-U ̈ F E}$ 'de meydana gelen bir şokun $\pi_{t, T U ̈ F E}$ üzerindeki etkisinin 3 ay gibi kısa bir süre hissedildiğini ancak $\pi_{t, Y \dot{I}-U ̈ F E}$ 'de meydana gelen bir şokun $\pi_{t, T U ̈ F E}$ üzerindeki etkisinin 1 yılı aşan bir süre için hissedilir olduğunu göstermektedir. Diğer taraftan, $\pi_{t, T U ̈ F E}$ 'de meydana gelen bir şokun $\pi_{t, T A R I M-U ̈ F E}$ üzerindeki etkisinin belirgin olmadığı, $\pi_{t, Y \dot{I}-U ̈ F E}$ 'de meydana gelen bir şokun ise $\pi_{t, Y \grave{I}-U ̈ F E}$ 'deki etkilerinin 6 . aydan sonra hissedilir olduğu gözlemlenmektedir. Son olarak, $\pi_{t, T U ̈ F E}$ 'de meydana gelen bir şokun $\pi_{t, Y \dot{I}-U ̈ F E}$ üzerinde 3 ay gibi kısa bir süre için hissedildiği ancak $\pi_{t, T A R I M-U ̈ F E}$ 'de meydana gelen bir şokun $\pi_{t, Y \dot{I}-U ̈ F E}$ üzerindeki etkisinin hissedilir olmadığı görülmektedir.

Tablo $6^{\prime}$ da ise $\pi_{t, T U ̈ F E}, \pi_{t, T A R I M-U ̈ F E}$ ve $\pi_{t, Y \dot{I}-U ̈ F E}$ 'nin öngörü hatası varyanslarının ayrıştırma analizi sonuçları sunulmuştur. Elde edilen sonuçlar, etki-tepki fonksiyonu sonuçları ile benzer noktalara işaret etmektedir. $\pi_{t, T U ̈ F E}$ 'nin öngörü hatasının varyansına katkıyı $\pi_{t, Y \dot{I}-U ̈ F E}$ değişkeni yapmakta ve dönem sayısı arttıkça bu katkı artmaktadır. 12 ay sonunda $\pi_{t, T U ̈ F E}$ 'nin öngörü hatasının varyansının \%75,90'lık kısmının $\pi_{t, Y \mathfrak{I}-U ̈ F E}$ tarafından açıklandığı görülmektedir. $\pi_{t, T A R I M-U ̈ F E}$ 'nin öngörü hatasının varyansının 6 . aydan sonra $\pi_{t, Y \dot{I}-U ̈ F E}$ tarafından açıklanabildiği ve 12 . ayın sonunda \%36,1'lik kısmının $\pi_{t, Y \dot{I}-U ̈ F E}$ tarafından açıklandığı gözlemlenmiştir. Son olarak, $\pi_{t, Y \dot{I}-U ̈ F E}$ 'nin öngörü hatasının varyansının büyük kısımının kendisi tarafından açıklandığı, $\pi_{t, T U ̈ F E}$ tarafından açıklanan oranın 12 ay sonra yaklaşık $\% 10$ olduğu görülmüştür. 
Şekil 1. Etki-Tepki Fonksiyonu Analizi Sonuçları
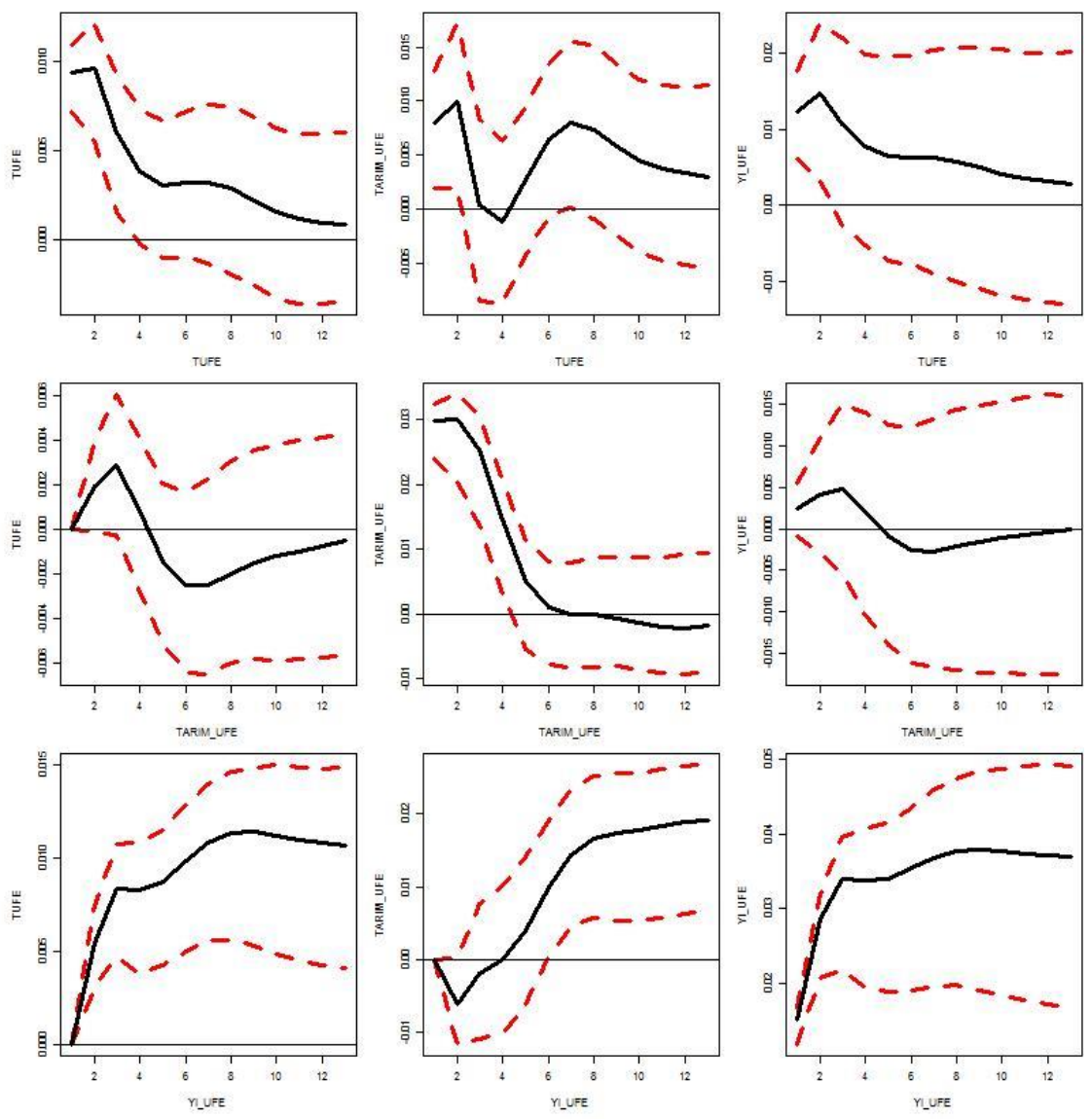

Tablo 6. Öngörü Hatasının Varyans Ayrıştırma Analizi Sonuçları

\begin{tabular}{|c|c|c|c|c|c|c|c|c|c|}
\hline \multirow[b]{2}{*}{ Dönem } & \multicolumn{3}{|c|}{$\pi_{t, T \mathrm{U} F E}$} & \multicolumn{3}{|c|}{$\pi_{t, T A R I M-U ̈ F E}$} & \multicolumn{3}{|c|}{$\pi_{t, Y \dot{I}-\ddot{U} F E}$} \\
\hline & $\pi_{t, T \ddot{U} F E}$ & $\pi_{t, T A R I M-U ̈ F E}$ & $\pi_{t, Y \dot{\mathrm{I}}-\ddot{U} F E}$ & $\pi_{t, T \ddot{U} F E}$ & $\pi_{t, T A R I M-U ̈ F E}$ & $\pi_{t, Y \dot{\mathrm{I}}-\ddot{U} F E}$ & $\pi_{t, T \ddot{U} F E}$ & $\pi_{t, T A R I M-U ̈ F E}$ & $\pi_{t, Y \dot{\mathrm{I}}-\ddot{U} F E}$ \\
\hline 1 & 100,00 & 0,00 & 0,00 & 6,01 & 93,99 & 0,00 & 41,59 & 1,40 & 57,01 \\
\hline 2 & 81,98 & 1,65 & 16,37 & 6,96 & 91,34 & 1,71 & 27,99 & 1,44 & 70,57 \\
\hline 3 & 62,69 & 3,13 & 34,19 & 5,27 & 93,37 & 1,36 & 20,31 & 1,43 & 78,26 \\
\hline 4 & 52,96 & 2,51 & 44,54 & 5,05 & 93,69 & 1,26 & 16,69 & 1,05 & 82,26 \\
\hline 5 & 45,62 & 2,63 & 51,75 & 5,14 & 93,16 & 1,71 & 14,60 & 0,84 & 84,55 \\
\hline 6 & 39,33 & 3,16 & 57,51 & 6,25 & 89,08 & 4,68 & 13,23 & 0,79 & 85,98 \\
\hline 7 & 34,33 & 3,32 & 62,34 & 7,78 & 81,93 & 10,29 & 12,24 & 0,75 & 87,00 \\
\hline 8 & 30,47 & 3,17 & 66,36 & 8,76 & 74,67 & 16,57 & 11,44 & 0,70 & 87,86 \\
\hline 9 & 27,48 & 2,94 & 69,58 & 9,13 & 68,53 & 22,33 & 10,75 & 0,64 & 88,61 \\
\hline 10 & 25,14 & 2,73 & 72,14 & 9,21 & 63,39 & 27,41 & 10,16 & 0,59 & 89,25 \\
\hline 11 & 23,26 & 2,55 & 74,19 & 9,16 & 58,88 & 31,96 & 9,67 & 0,54 & 89,79 \\
\hline 12 & 21,72 & 2,38 & 75,90 & 9,06 & 54,83 & 36,11 & 9,25 & 0,51 & 90,24 \\
\hline
\end{tabular}


$\pi_{t, T U ̈ F E}, \pi_{t, T A R I M-U ̈ F E}$ ve $\pi_{t, Y \dot{I}-U ̈ F E}$ arasında kısa dönemli dinamikleri görmek için 2 gecikme uzunluğuna sahip bir VEC modeli tahmin edilmiştir. VEC modeli, $\pi_{t, T U ̈ F E}, \pi_{t, T A R I M-U ̈ F E}$ ve $\pi_{t, Y \dot{I}-U ̈ F E}$ 'nin durağan olduğu seviyede kurulmuş modelleri içermektedir. Her bir modelde, iki hata düzeltme vektörü ve $\Delta \pi_{t, T U ̈ F E}, \Delta \pi_{t, T A R I M-U ̈ F E}$ ve $\Delta \pi_{t, Y \grave{I}-U ̈ F E}$ 'nin değişkenlerinin gecikmeleri bulunmaktadır. Elde edilen tahmin sonuçları Tablo 7 'te sunulmuştur.

Tablo 7' de $E C T_{(-1)}$ hata düzeltme teriminin 1. gecikmesini, $E C T_{(-2)}$ ise 2. gecikmesini temsil etmektedir. Görüldüğüü üzere, $\mathrm{ECT}_{(-1)}$ terimi $\Delta \pi_{t, T U ̈ F E}$ ve $\Delta \pi_{t, Y \dot{\mathrm{I}}-\ddot{U} F E}$ için kurulan modellerde negatif ve istatistiksel olarak \%1 seviyesinde anlamlıdır. $\Delta \pi_{t, T A R I M-U ̈ F E}$ için kurulan modelde ise $\mathrm{ECT}_{(-2)}$ terimi negatif ve istatistiksel olarak anlamlıdır. $\mathrm{ECT}_{(-2)}$ teriminin $\Delta \pi_{t, T U ̈ F E}$ için kurulan modelde de \%10 seviyesinde istatistiksel olarak anlamlı olduğu söylenebilir. VEC modellerindeki hata düzeltme terimlerinin negatif olması, tüm değişkenler arasında yakınsamanın olduğunu göstermektedir. VEC modelinde sırasıyla otokorelasyon ve değişen varyans problemlerinin varlığını araştıran Breusch-Godfrey ve Breusch-Pagan testlerinin sonucunda problemlerin olduğuna dair boş hipotezler, $\chi_{1}^{2}$ ve $\chi_{8}^{2}$ serbestlik derecelerinde $\% 1$ anlamlılık düzeyinde reddedilememiştir.

Tablo 7'nin alt kısmında fiyat endeksleri için yapılan Granger nedensellik testleri bulunmaktadır. $\chi_{2}^{2}$ serbestlik derecesinde değerlendirilen Wald test sonuçları, $\Delta \pi_{t}{ }_{t}^{\prime} l e r i n$ \%1 anlamlılık düzeyinde birbiri üzerinde nedensellik ilişkisine sahip olduğunu işaret etmektedir. Bununla birlikte, katsayı değerleri dikkate alındığında daha detaylı sonuçlar çıkarmak mümkündür. Özellikle $\Delta \pi_{t, T U ̈ F E}{ }^{\prime} \operatorname{nin} \Delta \pi_{t, T A R I M-U ̈ F E}$ ve $\Delta \pi_{t, Y \dot{I}-U ̈ F E}$ üzerindeki nedensellik etkilerinin daha güçlü olduğu söylenebilir. $\Delta \pi_{t, Y \dot{I}-U ̈ F E}$ 'nin $\Delta \pi_{t, T U ̈ F E}$ üzerindeki nedensellik etkisi de nispeten yüksek bulunmuştur.

Tablo 7. VEC Modeli Tahmin Sonuçları

\begin{tabular}{|c|c|c|c|}
\hline \multirow[b]{2}{*}{ Bağımsız değişkenler } & \multicolumn{3}{|c|}{ Bağımlı değişken } \\
\hline & $\Delta \pi_{t, T U ̈ F E}$ & $\Delta \pi_{t, T A R I M-U ̈ F E}$ & $\Delta \pi_{t, Y \dot{I}-\mathrm{U} F E}$ \\
\hline $\mathrm{ECT}_{(-1)}$ & $-0,425^{* * *}(0,085)$ & $-0,051(0,276)$ & $-0,364^{* *}(0,182)$ \\
\hline $\mathrm{ECT}_{(-2)}$ & $-0,035^{*}(0,019)$ & $-0,314^{* * *}(0,062)$ & $-0,064(0,041)$ \\
\hline$\Delta \pi_{t-1, T U ̈ F E}$ & $-0,110(0,126)$ & $0,703^{*}(0,408)$ & $-0,567^{* *}(0,269)$ \\
\hline$\Delta \pi_{t-1, T A R I M-\ddot{U} F E}$ & $0,056^{*}(0,029)$ & $0,341^{* * *}(0,093)$ & $0,022(0,061)$ \\
\hline$\Delta \pi_{t-1, Y \dot{\mathrm{I}}-\mathrm{U} F E}$ & $0,209^{* * *}(0,064)$ & $-0,618^{* * *}(0,209)$ & $0,708^{* * *}(0,138)$ \\
\hline$\Delta \pi_{t-2, T \mathrm{U} F E}$ & $-0,267^{* *}(0,133)$ & $-1,413^{* * *}(0,430)$ & $-0,363(0,284)$ \\
\hline$\Delta \pi_{t-2, T A R I M-\ddot{U} F E}$ & $0,079^{* * *}(0,029)$ & $0,141(0,095)$ & $0,102(0,063)$ \\
\hline$\Delta \pi_{t-2, Y \dot{I}-U ̈ F E}$ & $-0,037(0,074)$ & $0,328(0,239)$ & $-0,180(0,158)$ \\
\hline Breusch-Godfrey test $\left(\chi^{2}{ }_{1}\right)$ & 1,582 & 0,657 & 2,129 \\
\hline Breusch-Pagan test $\left(\chi_{8}^{2}\right)$ & 9,018 & 4,887 & 3,003 \\
\hline$\Delta \pi_{t-1, t-2, T u ̈ F E}$ nedensellik testi $\left(\chi^{2}{ }_{2}\right)$ & . & $155,471^{* * *}$ & $25,71^{* * *}$ \\
\hline$\Delta \pi_{t-1, t-2, T A R I M-U ̈ F E}$ nedensellik testi $\left(\chi^{2}{ }_{2}\right)$ & $11,455^{* * *}$ & & $12,874^{* * *}$ \\
\hline$\Delta \pi_{t-1, t-2, Y I-U ̈ F E}$ nedensellik testi $\left(\chi^{2}{ }_{2}\right)$ & $10,725^{* * *}$ & $95,613^{* * *}$ & - \\
\hline Gözlem sayısı & 111 & 111 & 111 \\
\hline
\end{tabular}

${ }^{* * *} p<0,01 ;{ }^{* *} p<0,05 ;{ }^{*} p<0,1$, Parantez içindeki değerler standart hatalardır.

Bu çalışmada, $\pi_{t, T U ̈ F E}, \pi_{t, T A R I M-U ̈ F E}$ ve $\pi_{t, Y \dot{I}-U ̈ F E}$ arasındaki uzun dönemli ilişkilerin analizi, VEC modelinin ima ettiği uzun dönem katsayılarının yanında sistem denklemleri tahmin yöntemleri kullanılarak yapılmıştır. VEC modelinin ima ettiği uzun dönem katsayıları ile (3) numaralı eşitlikte ifade edilen sistem denkleminin EKK, 2AEKK, 3AEKK ve SUR yöntemleri ile tahmin sonuçları Tablo 8'de raporlanmıştır. Tablo yorumuna geçmeden önce, 2AEKK ve 3AEKK yöntemleri sonuçları arasında yapılan Hausman testi sonuçlarının sunulmasında fayda vardır. Hausman test istatistiği 2,454 olarak hesaplanmış ve bu test istatistiği ki-kare dağılımında 9 serbestlik derecesinde 0,9821 olasılık değerine karşlık gelmektedir. Bu durumda 3AEKK 
tahmincisinin tutarlı olduğu boş hipotezi reddedilemediği anlaşılmaktadır. Dolayısıyla, 3AEKK tahmincisinin tutarlı olduğunu varsayılabilir.

Tablo 8'de $\pi_{t, T U ̈ F E}, \pi_{t, T A R I M-U ̈ F E}$ ve $\pi_{t, Y \dot{I}-U ̈ F E}$ 'nin uzun dönemli etkileşimleri görülmektedir. $\pi_{t, T U ̈ F E}$ 'nin uzun dönemde $\pi_{t, T A R I M-U ̈ F E}$ üzerindeki etkisi sistem denklemleri tahminlerinde pozitif ve istatistiksel olarak anlamlı bulunmuştur. VEC tahmininden elde edilen katsayı negatif ve istatistiksel olarak anlamsızdır. Sistem denklemi tahminlerine göre $\pi_{t, T U ̈ F E}$ 'deki 10 puanlık bir artışın $\pi_{t, T A R I M-U ̈ F E}$ üzerindeki 12,22-38,22 puan arasında bir artışa sebep olabileceği anlaşılmaktadır. Diğer taraftan, $\pi_{t, T U ̈ F E}$ 'nin uzun dönemde $\pi_{t, Y \dot{I}-U ̈ F E}$ üzerindeki etkisi de VEC modelinde pozitif ve istatistiksel olarak anlamsızken, sistem denklemleri tahminlerinde pozitif ve istatistiksel olarak anlamlı bulunmuştur. Bu bulgu, $\pi_{t, T U ̈ F E}$ 'deki 10 puanlık bir artışın $\pi_{t, Y \dot{I}-U ̈ F E}$ üzerinde 19,75-26,75 puan arasında bir artışa sebep olabileceğini göstermektedir.

$\pi_{t, T A R I M-U ̈ F E}$ ve $\pi_{t, Y \dot{I}-U ̈ F E}$ 'nin $\pi_{t, T U ̈ F E}$ üzerindeki uzun dönemli etkilerine bakıldığında, istatistiksel olarak anlamlı ancak nispeten zayıf olduğu görülmektedir. VEC ve sistem denklemi tahmin yöntemlerinden elde edilen katsayılara bakıldığında, $\pi_{t, Y \dot{I}-U ̈ F E}$ 'de 10 puanlık bir artış $\pi_{t, T U ̈ F E}$ 'de 2,96-3,93 puan arasında bir artışa neden olacağı anlaşılmaktadır.

Tablo 1. Uzun Dönem Model Tahminleri

\begin{tabular}{|c|c|c|c|c|c|c|}
\hline $\begin{array}{l}\text { Bağımlı } \\
\text { Değişken }\end{array}$ & $\begin{array}{l}\text { Bağımsız } \\
\text { Değişkenler }\end{array}$ & VEC & EKK & 2AEKK & 3AEKK & SUR \\
\hline$\pi_{t, T \mathrm{U} F E}$ & $\beta_{1}$ & - & $0,052^{* * *}(0,003)$ & $0,048^{* * *}(0,010)$ & $0,036^{* * *}(0,007)$ & $0,044^{* * *}(0,003)$ \\
\hline$\pi_{t, T U ̈ F E}$ & $\pi_{t, T A R I M-U ̈ F E}$ & $-0,089^{* *}(0,05)$ & $0,104^{* * *}(0,026)$ & $0,185^{* *}(0,072)$ & $0,253^{* * *}(0,040)$ & $0,140^{* * *}(0,023)$ \\
\hline$\pi_{t, T U ̈ F E}$ & $\pi_{t, Y \dot{\mathrm{I}}-\mathrm{U} F E}$ & $0,296^{* * *}(0,04)$ & $0,353^{* * *}(0,022)$ & $0,318^{* * *}(0,079$ & $0,366^{* * *}(0,054)$ & $0,393^{* * *}(0,017)$ \\
\hline$\pi_{t, T A R I M-U ̈ F E}$ & $\beta_{2}$ & - & $-0,026(0,019)$ & $-0,114(0,072)$ & $-0,139^{* * *}(0,045)$ & $-0,049^{* * *}(0,017)$ \\
\hline$\pi_{t, T A R I M-\ddot{U} F E}$ & $\pi_{t, T \mathrm{U} F E}$ & $-0,151(0,89)$ & $1,222^{* * *}(0,304)$ & $2,952^{* * *}(1,083)$ & $3,822^{* * *}(0,606)$ & $1,642^{* * *}(0,267)$ \\
\hline$\pi_{t, T A R I M-\ddot{U} F E}$ & $\pi_{t, Y \dot{\mathrm{I}}-\mathrm{U} F E}$ & $0,422^{*}(0,31)$ & $-0,028(0,137)$ & $-0,798(0,497)$ & $-1,359^{* * *}(0,305)$ & $-0,201(0,124)$ \\
\hline$\pi_{t, Y \dot{\mathrm{I}}-\mathrm{U} F E}$ & $\beta_{3}$ & - & $-0,086^{* * *}(0,011)$ & $-0,090^{* *}(0,045)$ & $-0,097^{* * *}(0,033)$ & $-0,101^{* * *}(0,009)$ \\
\hline$\pi_{t, Y \dot{\mathrm{I}}-\ddot{\mathrm{U}} F E}$ & $\pi_{t, T A R I M-U ̈ F E}$ & $5,13^{* *}(3,05)$ & $-0,013(0,066)$ & $-0,370(0,230)$ & $-0,641^{* * *}(0,147)$ & $-0,096(0,059)$ \\
\hline$\pi_{t, Y \dot{\mathrm{I}}-\mathrm{U} F E}$ & $\pi_{t, T \mathrm{U} F E}$ & $1,225(1,35)$ & $1,975^{* * *}(0,124)$ & $2,348^{* * *}(0,551)$ & $2,675^{* * *}(0,379)$ & $2,203^{* * *}(0,093)$ \\
\hline \multicolumn{2}{|c|}{ Breusch-Godfrey test $\left(\chi^{2}{ }_{1}\right)$} & - & 0,673 & 0,546 & 0,932 & 0,345 \\
\hline \multicolumn{2}{|c|}{ Breusch-Pagan test $\left(\chi^{2}\right)$} & - & 8,348 & 6,315 & 7,993 & 5,742 \\
\hline \multicolumn{2}{|c|}{ Toplam Gözlem Sayısı } & 333 & 342 & 342 & 342 & 342 \\
\hline
\end{tabular}

${ }^{* * *} \mathrm{p}<0,01 ;{ }^{* *} \mathrm{p}<0,05,{ }^{*} \mathrm{p}<0,1$, Parantez içindeki değerler standart hatalardır.

$\pi_{t, T A R I M-U ̈ F E}$ 'nin $\pi_{t, T U ̈ F E}$ üzerindeki uzun dönemli etkisi, tüm tahmin yöntemlerinde istatistiksel olarak anlamlı bulunmuştur. Bununla birlikte VEC modelinden elde edilen katsayının negatif olduğu, sistem denklemlerinden elde edilen katsayıların pozitif olduğu görülmektedir. Bu doğrultuda, $\pi_{t, T A R I M-U ̈ F E}$ 'de 10 puanlık bir artışın, $\pi_{t, T U ̈ F E}$ üzerinde $-0,89$ ile $+2,53$ puan arasında bir değişime neden olacağı yorumu yapılabilir.

Tablo 8'deki sonuçlar genel olarak yorumlandığında, $\pi_{t, T U ̈ F E}$ 'nin $\pi_{t, T A R I M-U ̈ F E}$ ve $\pi_{t, Y \dot{I}-U ̈ F E}$ üzerindeki etkilerinin tersi yöndeki etkiden daha fazla olduğu sonucu çıkarılabilir. Bu sonuç, 2011-2020 dönemi için Türkiye'de tüketici fiyatlarından üretici fiyatlarında doğru etkileşimin daha hissedilir olduğunu göstermektedir. Dolayısıyla söz konusu dönemde artan talebe karşı kısıtlı arz sebebiyle ilk aşamada tüketici 
fiyatlarının arttığı, beraberinde arzın arttırılması amacıyla üreticinin girdi talebi nedeniyle üretici fiyatlarının arttığı sürecin geçerli olduğu görülmektedir. Üretici fiyatlarından tüketici fiyatlarına doğru ilişkinin ise nispeten daha zayıf olduğu görülmektedir. Bu bulgu ise girdi maliyetlerindeki artışların tüketici fiyatlarına daha az oranda yansıdığını göstermektedir. Çalışmada, tüketici fiyatlarına etki eden kalite ve vergi/kâr marjı gibi unsurlar dikkate alınmadığından böyle bir sonuç normaldir. Çünkü, üretici fiyatlarındaki değişim sonrasında tüketici fiyatlarına yansımayı düşük tutmak için ürünün kalitesinde değişime gidilebilmektedir. Diğer taraftan üreticiler ya da politika yapıcılar vergi/kâr marjını değiştirerek tüketiciye yansımayı düşük tutabilmektedir.

\section{Sonuç}

Üretici fiyatları ile tüketici fiyatları arasındaki ilişki literatürde tartışma yaratmıştır. Literatürde bu ilişki genelde TÜFE ve Yi-ÜFE arasında ve nedensellik-eşbütünleşme analiz yöntemleri kullanılarak araştırılmıştır. 2011 Ocak-2020 Haziran dönemini kapsayan bu çalışmada ise, TÜFE, TARIM-ÜFE ve Yi-ÜFE yıllık enflasyon oranları kullanılarak, ilişkinin üretici fiyatları kısmında ayrıştırmaya gidilmiştir. Hizmet sektöründeki fiyat değişimini ölçen HizMET-ÜFE endeksi yetersiz gözlem sayısına sahip olduğu için analiz dışında bırakılmıştır. Kısa dönemli dinamikler, etki-tepki fonksiyonları ve öngörü hatasının varyans ayrıştırması analizlerinin yanında VEC modeli üzerinden Granger nedensellik testleri ile detaylandırılmıştır. Uzun dönemli dinamikler ise VEC modelinin ima ettiği uzun dönem katsayılarının yanında sistem denklemi çerçevesinde EKK, 2AEKK, 3AEKK ve SUR yöntemleri kullanılarak ortaya konulmaya çalışılmışır.

Çalışmada uygulanan beş farklı durağanlık testinin sonuçları, TÜFE, TARIM-ÜFE ve Yi-ÜFE aylık enflasyon oranlarının I(1) entegrasyon derecesinde sahip olduğunu, diğer bir ifadeyle birinci farkında ve aynı entegrasyon derecesinde durağan olduklarını göstermektedir. Uygulanan Johansen, Lütkepol ve yapısal kırılmalı Johansen eşbütünleşme testleri sonucunda TÜFE, TARIM-ÜFE ve Yi-ÜFE yıllık enflasyon oranları arasında uzun dönemli bir ilişkinin olduğu ve bu ilişkinin iki eşbütünleşme vektörü ile temsil edilebildiği anlaşılmıştır.

Çalışmada elde edilen bulgular, literatürde Türkiye için yapılan çalışmaların içinden tüketici fiyatları ile üretici fiyatları arasında iki yönlü ilişki olduğunu iddia eden çalışmaları destekler niteliktedir. Kısa dönem perspektifinde yapılan analizler sonucunda TÜFE, TARIM-ÜFE ve Yi-ÜFE yıllık enflasyon oranları arasında istatistiksel olarak anlamlı nedensellik ilişkilerinin olduğu anlaşılmıştır. Özellikle, TÜFE'den TARIM-ÜFE ve YiÜFE'ye doğru, Yi-ÜFE'den TARIM-ÜFE'ye doğru ve Yi-ÜFE'den TÜFE'ye doğru etkileşimlerin hissedilir büyüklükte olduğu ortaya konmuştur. Uzun dönemli analiz sonuçları da kısa dönemli analiz bulgularını destekler niteliktedir. TÜFE'den TARIM-ÜFE ve Yi-ÜFE'ye doğru etkilerin oldukça yüksek seviyede olduğu, diğer taraftan TARIM-ÜFE ve Yi-ÜFE'den TÜFE'ye doğru etkilerin nispeten zayıf kaldığı görülmüştür.

Elde edilen sonuçlar genel olarak değerlendirildiğinde Türkiye'de tüketici fiyatları ile üretici fiyatları arasında iki yönlü kısa ve uzun dönemli ilişki olduğu iddia edilebilir. Ancak, ilişkinin büyüklüğünde farklılıklar mevcuttur. Tüketici fiyatlarındaki değişimle birlikte üretici fiyatlarının hissedilir düzeyde değiştiği, üretici fiyatlarındaki değişimlere karşı ise tüketici fiyatlarının benzer seviyede tepki vermediği değerlendirilmektedir. Bu bulgudan hareketle Türkiye'de talep kaynaklı enflasyonun daha etkin olduğu iddia edilebilir ancak maliyet kaynaklı enflasyonun da varlığı reddedilememiştir. Bu bulgu, Türkiye'de talep kaynaklı enflasyonun daha etkili olduğunun tespiti açısından önemlidir.

Bu noktada, tüketici fiyatlarındaki değişimin ölçüldüğg̈ TÜFE endeksinde vergiler dahil fiyatların kapsandığının vurgulanması gerekmektedir. Ayrıca, tüketici fiyatlarını etkileyebilecek olan kâr marjı gibi nicel ya da ürün kalitesi gibi nitel faktörler analize dahil edilmediği için tüketici fiyatlarının üretici fiyatlarına tepkisinin nispeten düşük bulunması beklentiler dahilindedir. Fiyat endeksleri arasındaki ilişkileri konu alan analizlerde ürünlerin kâr marjı, ürün üzerindeki vergiler ve ürün kalitesini ölçen değişkenlerin kullanılabilmesiyle kısa ve uzun dönemli dinamiklerin daha net anlaşılabileceği değerlendirilmektedir. 


\section{Beyan ve Açıklamalar (Disclosure Statements)}

1. Bu çalışmanın yazarı, araştırma ve yayın etiği ilkelerine uyduğunu kabul etmektedir (The author of this article confirms that her work complies with the principles of research and publication ethics).

2. Yazar tarafından herhangi bir çıkar çatışması beyan edilmemiştir (No potential conflict of interest was reported by the author).

3. Bu çalışma, intihal tarama programı kullanılarak intihal taramasından geçirilmiștir (This article was screened for potential plagiarism using a plagiarism screening program).

\section{Kaynaklar}

Abdioğlu, Z., \& Korkmaz, Ö. (2012). Tüketici ve üretici fiyat endekslerinde fiyat geçişkenliği: Alt sektörler. Çukurova Üniversitesi Iktisadi ve Idari Bilimler Fakültesi Dergisi, 16(2), 65-81.

Akçay, S. (2011). The causal relationship between producer price index and consumer price index: Empirical evidence from selected European countries. International Journal of Economics and Finance, 3(6), 227-232.

Akdi, Y., Berument, H., \& Cilasun, S. M. (2006). The relationship between different price Indices: Evidence from Turkey. Physica A: Statistical Mechanics and Its Applications, 360(2), 483-492.

Blomberg, S. B., \& Ethan, S. H. (1995). The commodity-consumer price connection: Fact or fable? Economic Policy Review, 1(3), 21-38.

Clark, T. (1995). Do producer prices lead consumer prices? Economic Review, 80, Q(III), 25-39.

Dickey, D. A., \& Fuller, W.A. (1981). Likelihood ratio statistics for autoregressive time series with a unit root. Econometrica, 49(4), 1057-1072.

Elliott, G., \& Rothenberg, T. J., \& Stock, J. H. (1996). Efficient tests for an autoregressive unit root. Econometrica, 64(4), 813-836.

Erdem, F., \& Yamak, R. (2014). Üretici fiyat endeksi ve tüketici fiyat endeksi arasındaki geçişkenliğin derecesi. Anadolu University Journal of Social Sciences, 14(4), 1-13.

Granger, C. W. J., \& Newbold, P. (1974). Spurious regressions in Econometrics. Journal of Econometrics, 2(2), 111-120.

Gómez, V., \& Maravall Herrero, A. (1998). Automatic modeling methods for univariate series. Servicio de Estudios, Banco de España.

Gujarati, D. N. (2009). Basic econometrics. Tata McGraw-Hill Education.

Hausman, J. A. (1978). Specification tests in Econometrics. Econometrica, 46(6), 1251-1271.

Johansen, S. (1991). Estimation and hypothesis testing of cointegration vectors in gaussian vector autoregressive models. Econometrica, 59(6), 1551-1580.

Kwiatkowski, D., Phillips, P. C. B., Peter, S., \& Shin, Y. (1992). Testing the null hypothesis of stationarity against the alternative of a unit root: How sure are we that economic time series have a unit root? Journal of Econometrics, 54(1), 159-178.

Lütkepohl, H. (2005). New introduction to multiple time series analysis. Springer Science \& Business Media.

Lütkepohl, H., Saikkonen, P., \& Carsten, T. (2004). Testing for the cointegrating rank of a var process with level shift at unknown time. Econometrica, 72(2), 647-662.

Oehlert, G. W. (1992). A note on the delta method. The American Statistician, 46(1), 27-29.

Osterwald-Lenum, M. (1992). A note with quantiles of the asymptotic distribution of the maximum likelihood cointegration rank test Statistics. Oxford Bulletin of Economics and Statistics, 54(3), 461-472.

Öner, H. (2018). Tüketici ve üretici fiyat endeksleri arasındaki ilişkinin granger nedensellik testi yoluyla incelenmesi. Finans Ekonomi ve Sosyal Araştırmalar Dergisi (FESA), 3(1), 318-327.

Pesaran, M. H., Shin, Y., \& Smith, R. J. (2001). Bounds testing approaches to the analysis of level relationships. Journal of Applied Econometrics, 16(3), 289-326.

Phillips, P., \& Perron, P. (1988). Testing for a unit root in time series regression. Biometrika, 75(2), 335-346.

Saatçioğlu, C., \& Orhan K. (2017). Türkiye'de üretici fiyatları ile tüketici fiyatları arasındaki nedensellik ilişkisi: 2005-2016. Sakarya iktisat Dergisi, 6(2), 1-16. 
Saraç, T. B., \& Karagöz, K. (2010). Türkiye'de tüketici ve üretici fiyatları arasındaki ilişki: Yapısal kırılma ve sınır testi. Maliye Dergisi, 159, 220-232.

Shahbaz, M., Tiwari, A. K., \& Tahir, M. I. (2012). Does cpi granger-cause wpi? New extensions from frequency domain approach in Pakistan. Economic Modelling, 29 (5), 1592-1597.

Sui, J., \& Li, Y. (2019). Internal driving mechanism between cpi ve ppi on the view of regime switching Causality. Systems Engineering - Theory \& Practice, 39(4), 1001-1017.

Şahinöz, S., Demirhan, A. A., \& Coşar, E. E. (2007). Üretici fiyatlarından tüketici fiyatlarına geçişkenliğin farklı yaklaşımlarla incelenmesi: Türkiye örneği. TiSK Akademi, 2(4), 224-246.

Terzi, H., \& Tütüncü, A. (2017). Türkiye'de üretici fiyat endeksi ve tüketici fiyat endeksi arasındaki ilişkinin incelenmesi: ARDL sinir testi yaklaşımı. Sosyoekonomi, 25(34), 173-186.

Tiwari, A. K. (2012). An empirical investigation of causality between producers' price and consumers' price indices in Australia in frequency domain. Economic Modelling, 29(5), 1571-1578.

Tiwari, A. K., \& Shahbaz, M. (2013). Modelling the relationship between whole sale price and consumer price indices: Cointegration and causality analysis for India. Global Business Review, 14(3),397-411.

Tiwari, A. K., Mutascu, M., \& Andries, A.M. (2013). Decomposing time-frequency relationship between producer price and consumer price indices in Romania through wavelet analysis. Economic Modelling, 31(1),151-159.

Tiwari, A. K., Suresh, K. G., Arouri, M., \& Teulon, F. (2014). Causality between consumer price and producer price: Evidence from Mexico. Economic Modelling, 36(1), 432-440.

Topuz, Y. V., Yazdifar, H., \& Sahadev, S. (2018). The relation between the producer and consumer price indices: A twocountry study. Journal of Revenue and Pricing Management, 17(3), 122-130.

TÜiK, (2008). Fiyat endeksleri ve enflasyon: Sorularla resmi istatistikler dizisi-3. Türkiye İstatistik Kurumu Yayınları.

Trenkler, C. (2003). A new set of critical values for systems cointegration tests with a prior adjustment for deterministic terms. Economics Bulletin, 3(11), 1-9.

Yamak, R., \& Topbaş, F. (2008). Fiyat endeksleri arasındaki geçişkenlik ilişkisi: Enders-Ludlow nonlineer eş bütünleşme analizi. Dokuzuncu Ekonometri ve İstatistik Sempozyumunda Sunulmuş Bildiri, İzmir.

Yıldırım, Z. (2015). Enflasyon rejimleri ve üretici enflasyonundan tüketici enflasyonuna geçişkenlik. Central Bank Review, 15(3), 89-114.

Zellner, A. (1962). An efficient method of estimating seemingly unrelated regressions and tests for aggregation bias. Journal of the American Statistical Association, 57(298), 348-368.

Zellner, A., \& Theil, H. (1962). Three-stage least squares: Simultaneous estimation of simultaneous equations. Econometrica, 30(1), 54-78.

Zivot, E., \& Andrews, D. W. K. (1992). Further evidence on the great crash, the oil-price shock, and the unit-root hypothesis. Journal of Business \& Economic Statistics, 10(3), 251-270.

Zortuk, M. (2008). Türkiye'de tüketici ve toptan eşya fiyat indeksleri arasındaki nedensellik ilişkisi: 1986-2004. Dumlupınar Üniversitesi Sosyal Bilimler Dergisi, 20, 181-190. 
This Page Intentionally Left Blank 